\title{
The nexus between the economic growth and unemployment in Jordan
}

\author{
Hala Hjazeen, Mehdi Seraj ${ }^{*}$ (iD and Huseyin Ozdeser
}

\begin{abstract}
The main objective of this study is to investigate the impact of unemployment on Jordan's economy over the period 1991-2019. This study used the auto-regressive distributed lag (ARDL) model to investigate the relationship between the unemployment rate and the other variables. Also, we employ the ARDL bootstrap cointegration approach to examine the correlation and long-run relationship among the variables. The empirical finding indicated a long-run relationship between the unemployment rate, economic growth, education, female population, and urban population in Jordan. Our finding shows the negative linkage between economic growth and unemployment, and a positive relationship among the education, female population, and urban population and unemployment in Jordan.
\end{abstract}

Keywords: Unemployment, Economic Growth, Jordan economy

JEL Classifications: O43, E24, 123

\section{Introduction}

Jordan is a small country $(90,000 \mathrm{~km}$ square $)$ in the west of Asia, with a high population (9.702 million in 2019). Jordan suffers from some economic challenges, such as high rates of poverty, unemployment, inflation, large budget deficit, and public debt that is around $90 \%$ of GDP [20].

Unemployment is an important issue in developing countries. The high rate of unemployment means that the country is not using the labor resource efficiently. Unemployment is the greatest economic problem because of its negative effect on the individual and the society Amerah, and Khasawneh [10], and the speed of spreading in the world, such as the drug addiction (Anbaraki and Ismaili [11], Nagelhout et al. [27]), and crime in many countries [17].

The issue of unemployment in Jordan reached its highest level in 2019 (around 19\%). It created a state of the economic recession caused by a decrease in demand for goods and services that led to a decrease in the production rate. The unemployment problem in Jordan is very

\footnotetext{
*Correspondence: mehdi.seraj@neu.edu.tr
}

Department of Economics, Near East University, Nicosia, Cyprus serious, and it is mainly among the youth (15-24 years), $35 \%$ among males, and $40 \%$ among females. These drastic figures reflect unemployment among university graduates and school levers [19].

During the last five years, Jordan's economy has not shown any sign of positive growth to provide new job opportunities to absorb university graduates into the labor market. Government capital expenditure didn't grow much in the past few years due to the lack of resources and a reduction in tax revenue (Department of statistics, Jordan). The government was not spending enough money for production purposes. The private sectors couldn't complete their responsibilities and tasks in creating new projects and job opportunities because of the political instability around Jordan's borders in Syria and Iraq.

The main goal of this paper is to investigate the nexus among the unemployment rate and education, economic growth, urban population, and female population in Jordan from 1991 to 2019 (Fig. 1).

Jordan is suffering from the lack of natural resources, while the majority of Middle East countries have so much oil, gas, and other mineral resources. This shortage of resources is one of the main reasons for the low GDP 
UN

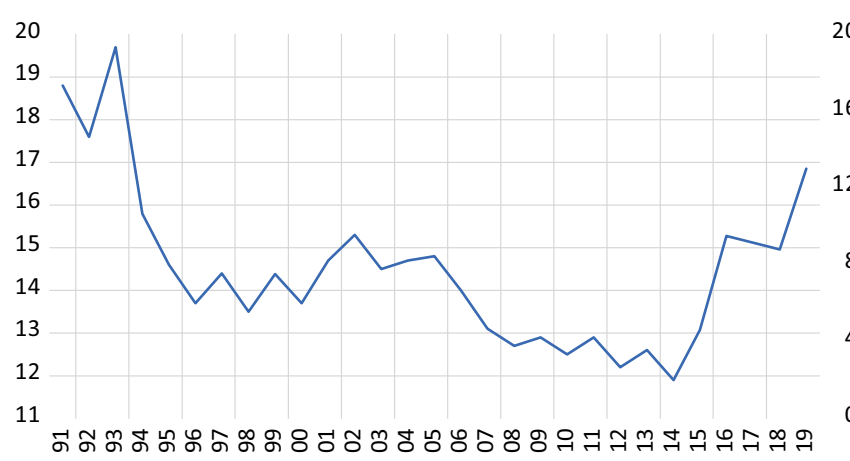

GR

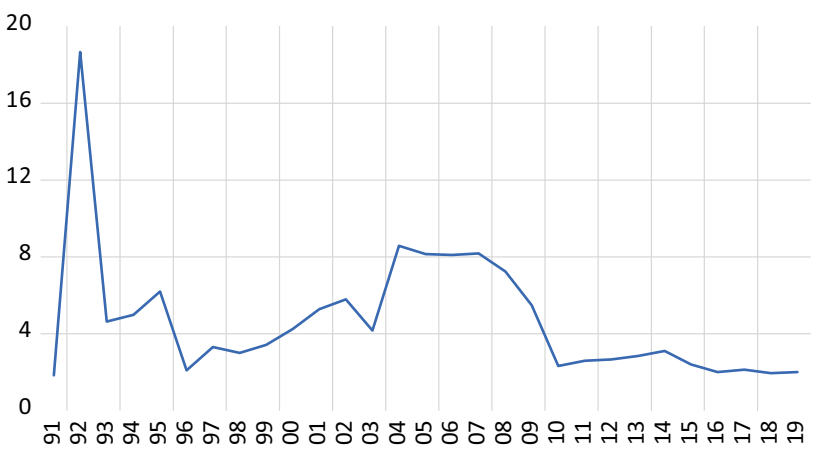

Fig. 1 Unemployment rate and GDP growth in Jordan for 1991-2019

in Jordan. Also low national income and small investment because of the high tax rates are the another reason of low GDP in Jordan. When the unemployment rate is reduced, the economy will be in the full capability of its production and the economy will be powerful as it increases consumption and purchasing power.

Although Jordan has a high population and it's also one of the most well-educated countries in the region especially the youth. There are many reasons for unemployment, but the most important reasons are; first of all, the young Jordanian have been educated in a field that does not match with the demand for the labor in market (Supply of labor cannot respond the demand for labor), secondly, the high ratio of foreign labors work in the minimum wage (it decrease the demand for local labor), thirdly, there is the weakness of the public sector and a lack of public investment.

The relationship between economic growth and unemployment shows that there is a high correlation between the economic growth rate and the decrease in unemployment rates. An increase in the growth rate increases the employment rate or decreases the unemployment rate. The relationship between economic growth and unemployment has been studied experimentally in the economic literature based on what is known as the Okun law, which shows that there is an inversely proportional relationship between the change in the growth rate (GDP) and the change in the unemployment rate. Okun [30] has succeeded to show that there is a reciprocal correlation between unemployment and economic growth. He found that if unemployment decreased by (1\%), then this would be due to an increase in real gross domestic product (RGDP) by (3\%) and vice versa, and when an increase in the RGDP occurs, an increase in employment is achieved.
It has been observed that there is an application of supply and demand theory that can be applied in this case. Similarly, the Keynesian Economics theory is also presented by Eichengreen [15] that applied different factors of macroeconomics to understand the aspects of economics and the methods of employment. As referred to the study of Efrianti et al. [14], there are different statements and arguments provided by the authors regarding to the impact and relationship of employment and economic growth that have supported the different aspects of employment and economic growth. Based on the assessment of Soylu et al. [32] and Efrianti et al. [14], it has been highlighted that the increasing economic growth in any country brings a huge increase in the GDP and labor productivity that can be effective for creating the opportunities for employment in the country. Similarly, Chand et al. [12] have also supported the fact that the increasing economy can contribute toward the rapid growth of labor force and will ultimately decrease the rate of unemployment in the country. On the other hand, Mihajlović [25] has presented the arguments that the absence of productivity in any country can also result in failing economy in the country and may also give rise to unemployment in this regard. The government and the policy makers have designed different methods that can contribute toward the increasing rate of employment and can provide better quality of life and standard of living to the people based on Al-Sawaiea et al. [8]. Therefore, it can be stated that the countries might get better means of economic growth that can support the common people in terms of getting the employment opportunities and contributing toward the overall progress and profitability of the country. However, there is one reason that can cause unemployment not to be related to the economic factors that include the company's recession period and 
jobs are not utilized in an effective manner and it causes the demand of products to be affected [16].

Economic growth is the main goal of the governments that is an indicator of welfare, quality of living standard, and reduction in poverty. Some studies have empirically examined the linkage between economic growth and unemployment by implementing Okun's law. Al-Habees [5] studied the linkage between unemployment and the economic growth in some Arab countries, and focused on Jordan as the main case study, by adopting a simple model of Okun law. The results showed a significant correlation exists between growth and changing rates of unemployment and revealed the efficiency of the economic policies strive to reduce the unemployment rate with a balanced rate of economic growth. Also, Kreishan, [23], accounted for the linkage between unemployment and economic growth in Jordan along with the enforcement of Okun's law and Augmented Dickey-Fuller (ADF) for unit root for the period 1970-2008, founded that the shortage of economic growth doesn't clarify the unemployment phenomena in Jordan.

Akeju and Olanipekun [3] examined the Okun's law in Nigeria to investigate the linkage between unemployment and economic growth by using ECM and ARDL Johansen cointegration test which led to a noteworthy linkage between unemployment and economic growth.

Abdul-khaliq [1] tested that the linkage between unemployment and gross domestic product growth in nine Arab Countries throughout 1994 and 2010. He found a noteworthy negative effect of growth on the unemployment rate and a positive relationship between the population growth rate and the unemployment rate. Rahman, [31], studied the relationship through GDP, GDP per capita, literacy rate, and the unemployment rate in OECD countries and found that GDP is not significantly related to GDP per capita, literacy rate or unemployment rate.

Khrais and ve Al-Wadi [22] studied the linkage between economic growth and unemployment in MENA countries in the period of 1990 to 2016, using simple linear regression, and found a weak linkage among the mentioned variables. Alawin [4], tried to show the linkage between trade balance and the unemployment rate in Jordan over thirteen years between 2000 and 2012, using the ADF test and Johansen's co-integration, and he understood that decline in the trade balance can increase the unemployment rate, and unemployment can have a negative effect in the trade balance in the short-run.

Additionally, Soylu et al. [33] examined the linkage between unemployment and economic growth based on Okun's law (which reflects the linkage among the unemployment and economic growth) in Eastern European Countries from 1992 to 2014 and found cointegration among the unemployment and GDP growth (negative relationship). Also, Noor et al. [28] have a similar study for the correlation among unemployment and the Malaysian economy by Okun's law and discover a negative correlation among the output and unemployment.

Nagel [26] discussed the correlation between GDP growth and unemployment and found a negative correlation between economic growth and unemployment. Besides, Ahmed [2] examined the relationship between the unemployment rate and growth rate in selected SAARC countries (Bangladesh, Bhutan, India, Pakistan, and Sri Lanka) throughout 1990-2010, using OLS and found a sign of the correlation among the economic growth rate and unemployment rate vary between the SAARC countries.

After that, Ali and Allan [6] claimed that economic growth has a positive and statistically significant impact on unemployment in Jordan over the period from 1991 to 2015. Moh'd AL-Tamimi and Mohammad (2019) studied the impact of the unemployment rate on the economic growth in Jordan throughout 2009 and 2016 by using the OLS approach and found an insignificant impact of the unemployment rate (in total labor) on the economic growth.

Magnani [24] wanted to expand the Solow model which can define the unemployment explicated by the shortage of the aggregate demand which resulted as the increase in the aggregate demand will reduce the unemployment catalyze the GDP. Xesibe [34] studied the effect of unemployment on GDP growth in South Africa from 1994 to 2017. The results had shown that there is a negative correlation between the unemployment rate and economic growth rate in South Africa.

Finally, Ojima [29] examined the relationship among the unemployment and economic development in Nigeria for 35 years span from 1980 to 2017 and found that unemployment hurt economic development for Nigeria with an adverse linkage among the unemployment and economic development in Nigeria and recommended a fiscal and monetary policy in the purpose of creating job opportunities to sustain the economic growth for Nigeria. Dahmani, [13], found a negative relationship between the variables in the long-run, whereas in the short-run there was no correlation between unemployment and the economic growth in Algeria throughout 1970-2014.

\section{Methods}

Arthur Okun (1962) studied the US economy, and he proved the inverse relationship between the unemployment rate and the potential output. The theoretical ground of the relations Okun investigated is based on the fact that the increased workforce must produce more goods and services. Okun found that the unemployment rate declined in the years when the real 
growth rate was high, whereas the unemployment rate increased in the years when the real growth rate was low or even negative [18].

This study tries to analyze the nexus between the gross domestic production (GDP) growth and unemployment rate in Jordan from 1991 to 2019. Data collected from World Bank Database, which is the longest possible time series data which are available on all variables. We added some control variables on OKUN's model such as education, female population, and urban population that are the main sources of unemployment in Jordan Al-Manaseer and Al-Qudah [7], Alshyab et al. [9], Kasoolu et al. [21].

The study uses the following variables, and we use the definition of the variables according to world bank definitions:

Unemployment (UN) is the shortage of a job opportunity as compared to the availability of it and the continuous seeking for it. It can happen if there is a demand excess or supply shortage in the labor market. Definitions of the labor force and unemployment differ by country, which can be calculated using the following formula, Unemployment Rate $=$ Number of Unemployed Persons / Labor Force.

Economic growth (GR) is the yearly percentage of the GDP growth that is the summation of private consumption expenditures, investment or business expenditures, government expenditure on goods and services, and the nation's net export.

Education (EDU) is the total registration of the rate of total records, nevertheless of age, to the population of the age group that formally work in with the level of education. This can be accounted by the division of the number of registered students in a specific level of schooling by the total population that officially correlated to the specific level of schooling, and multiply the result by 100 .

Female Population (FEMALE) is the proportion of the inhabitance which is female without taking into consideration of legal status or citizenship, which can be calculated by the ratio of female*total population.

Urban Population (URBAN) is the population in the civil clot of further than one million that is the percentage of the population who are living in the cities by population more than one million.

The main goal of this research is to analyze the correlation between the economic growth rate and the unemployment rate in Jordan over the period 19912019. The methodological framework is:

1. Examine the stationary in the time series by implementing the Augmented Dickey-Fuller test (ADF).
2. Implement the ARDL Bootstrap cointegration test to establish if there is a correlation between the variables.

3. Test the long-run linkage between the variables by implementing auto-regressive distributed lag (ARDL).

Table 1 shows the descriptive analysis of the study variables. The results of the descriptive analysis show that the largest standard deviation from the mean belongs to EDU and it means that the fluctuation in this variable is more than other variables. Also, EDU has the highest central tendency, as represented by mean and it is left-skewed while other variables are right-skewed.

The model for estimation is specified in linear form as:

$$
\begin{aligned}
U N_{t}= & \alpha_{0}+\alpha_{1} \text { FEMALE }_{t}+\alpha_{2} G R_{t} \\
& +\alpha_{3} U R B A N_{t}+\alpha_{4} \text { ED }_{t+} \varepsilon_{t}
\end{aligned}
$$

where $\mathrm{UN}_{\mathrm{t}}$ is the unemployment rate at year $\mathrm{t}, \mathrm{GR}_{\mathrm{t}}$ : presents the economic growth at year $t, \mathrm{EDU}_{\mathrm{t}}$ shows the education at year $t$, FEMALE $_{t}$ presents the female population at year $t, \mathrm{URBAN}_{\mathrm{t}}$ shows the urban population at year $t$, and $\varepsilon_{t}$ shows the error term.

\section{ARDL (auto-regressive distributed lag) model and ARDL bootstrap cointegration model}

Autoregressive-distributed lag (ARDL) model developed by Pesaran et al. [31]. To conduct an estimation procedure of ARDL that would determine the contribution pattern of Female, GR, Urban, EDU to unemployment in Jordan, annual data covering the period of 1991 and 2019 is used, data obtained from World Bank

$$
U N=f(\text { Female, } G R, E D U, U R B A N)
$$

We delve into determining the long-run cointegration relationship of the variables using the bootstrap ARDL cointegration framework. The bootstrap ARDL bounds test has many merits over the ordinary ARLD bounds test according to Peseran et al. [31]. Firstly, it is able to overcome inconclusive inferences that is associated with

Table 1 Descriptive statistics

\begin{tabular}{llclll}
\hline & UN & FEMALE & GR & URBAN & EDU \\
\hline Mean & 14.49172 & 48.52356 & 4.729941 & 20.05723 & 77.78597 \\
Median & 14.40000 & 48.40822 & 3.409475 & 19.60214 & 80.08052 \\
Maximum & 19.70000 & 49.38968 & 18.66484 & 23.31466 & 85.90466 \\
Minimum & 11.90000 & 47.63253 & 1.823896 & 18.86926 & 62.63221 \\
Std. Dev & 1.879705 & 0.645022 & 3.448428 & 1.190451 & 7.563059 \\
Skewness & 1.108084 & 0.039312 & 2.402762 & 1.249076 & -0.859857 \\
Kurtosis & 3.977896 & 1.547784 & 10.16282 & 3.687360 & 2.370407 \\
\hline
\end{tabular}


the ordinary ARDL bounds test. Through the bootstrap method, critical values are derived on the principle of the integration nature of each data sets thus avoiding the chances of inconclusive test. The bootstrap method provides a robust test by considering the relevance of the lagged estimates of the repressor which gives a better understanding to the cointegration nature of the model. It can be executed more effectively and efficiently as a result of the size and power properties than the large sample test in the ARDL bounds test.

We begin by looking at the ARDL bound test according to Peseran et al. [31]

$$
\begin{aligned}
\Delta y_{t}= & a+\alpha y_{t-1}+\beta x_{t-1}+\sum_{i=1}^{p-1} \gamma \Delta y_{t-1} \\
& +\sum_{i=1}^{p-1} \delta \Delta x_{t-1}+\sum_{j=1}^{q} \varphi D_{t, j}+\varepsilon
\end{aligned}
$$

The model is thus transformed to

$$
y_{t}=c+\sum_{i=1}^{k} \alpha_{1} y_{t-i}+\sum_{i=1}^{k} \beta_{i} x_{t-i}+\sum_{j=1}^{I} \varphi_{j} D_{t, j}+u_{t}
$$

where $i$ and $j$ signify the lag period, $i=1,2, \ldots \ldots, k$; $j=1,2, \ldots \ldots, k ; t$ indicates time, $t=1,2, \ldots \ldots, T$. The $y_{t}$ is the explained variable and $x_{t}$ is the explanatory variable, $D_{t, j}$ is a dummy variable. $\alpha_{i}$ and $\beta_{i}$ are the parameters of the interpreted variable $y_{i}$ and the explanatory variable $x_{i}, u_{t}$ is the error term. Equation (2) is expanded as follows:

$$
\begin{aligned}
\Delta y_{t}= & \gamma_{0}+\sum_{i=1}^{k-1} \gamma_{1} \Delta y_{t-i}+\sum_{i=1}^{k-1} \gamma_{2} \Delta x_{t-i}+\sum_{i=1}^{k-1} \gamma_{3} \Delta x_{t i} \\
& +\sum_{j=1}^{I} \gamma_{4} D_{t, j}+\emptyset_{1} y_{t-1}+\emptyset_{2} x_{t-1}+\emptyset_{3} z_{t-1}
\end{aligned}
$$

where $\gamma=1-\sum_{i=0}^{k} \alpha, \emptyset=\sum_{i=0}^{k} \beta_{i}$.

The null hypothesis is $H_{0}: \emptyset=0$.

The bootstrap ARDL test is the cointegration relationship based on the following premise.

$$
H_{0}: \gamma=\emptyset=0, H_{0}: \gamma=0, H_{0}: \emptyset=0
$$

If cointegration exists between the explained variable and the explanatory variable, the null hypothesis will be rejected.

Once cointegration relationship is established, we proceed to estimate the autoregressive distributed lag model (ARDL). We use the ARDL to investigate the link between unemployment and its determining factors.
This method according to Peseran et al. [31] has numerous advantages over other estimation techniques. First, it accommodates a situation where variables are at different orders of integration i.e. whether I(0) or I(1) or a mixture. Secondly, this model has the capacity to estimate longrun and short-run estimates at the same time. The model allows for the inclusion of individual specific differences across the countries and sub-regions.

The ARDL model is a model with order $p$ in the dependent variable and order $q$ in the independent variables. Where the right-hand side of the model contains lags of the dependent variable and independent variables. It is typically represented as follows:

$$
y_{i t}=\sum_{j=1}^{p} \alpha_{i j} y_{i t-j}+\sum_{j=0}^{q} \beta_{i j} x_{i t-j}+u_{i}+\varepsilon_{i t}
$$

where $i=1,2, \cdots \cdots N, t=2001,2002, \cdots \cdots \cdots T, j$ is the number of time lags.

For our estimation, Eq. (4) becomes

$$
\begin{aligned}
\Delta \text { GINI }_{i t}= & \mathrm{B}_{i 0}+\phi G I N I_{i t-1}+\mathrm{B}_{i 1} U N E_{i t-1} \\
& +\mathrm{B}_{i 2} E C G_{i t-1}+\mathrm{B}_{i 3} C P I_{i t-1} \\
& +\mathrm{B}_{i 4} P O P_{i t-1}+\mathrm{B}_{i 5} T R G_{i t-1} \\
& +\sum_{j=1}^{p-1} \lambda_{i j} \Delta G I N I_{i t-1}+\sum_{j=0}^{q-1} \lambda_{i j}^{1} \Delta U N E_{i, t-j} \\
& +\sum_{j=0}^{q-1} \delta_{i j}^{2} \Delta E C G_{i, t-j}+\sum_{j=0}^{q-1} \delta_{i j}^{3} \Delta C P I_{i, t-j} \\
& +\sum_{j=0}^{q-1} \delta_{i j}^{4} \Delta P O P_{i, t-j}+\sum_{j=0}^{q-1} \delta_{i j}^{5} \Delta T R G_{i, t-j} \\
& +\lambda E C T_{t-1}+u_{i}+\varepsilon_{i t}
\end{aligned}
$$

The variables with the differences are the short-run variables while those without the difference are the longrun variables.

\section{Results and discussion}

The first step in the analysis is to test the time-series properties of the data by using the Augmented DickeyFuller (ADF) unit root tests. The test is applied in level and first difference and second difference of each series; by including the constant $(\mathrm{C})$ term, and both constant and trend $(\mathrm{C}+\mathrm{T})$ terms in the test equations.

Table 2 indicates ADF unit root test results of each time series in levels, first differences, and second differences. The null hypothesis (Ho: $\delta=0)$ for the test is that the variable under study includes a unit root, against the alternative hypothesis $(\mathrm{H} 1: \delta<0)$ that the variable does not contain a unit root. The null hypothesis is 
Table 2 Unit root test

\begin{tabular}{llll}
\hline Variable & Level & First Difference & \\
\hline UN & $0.0000^{*}$ & & $\mathrm{I}(0)$ \\
EDU & 0.1404 & 0.0333 & $\mathrm{I}(1)$ \\
FEMALE & 0.0435 & & $\mathrm{I}(0)$ \\
URBAN & 0.3330 & 0.0471 & $\mathrm{I}(1)$ \\
GR & 0.0022 & & $\mathrm{I}(0)$ \\
\hline
\end{tabular}

* These numbers show the $P$-Value

accepted if the test statistics in absolute value are less than the critical values, which means that the variable is non-stationary, while the null hypothesis is rejected if the test statistics in absolute value are greater than the critical values, which means that the variable is stationary, I (0). It can also be judged by the probability value, if the probability is less than (5\%), this indicates the stationary of the variable, as the null hypothesis assumes non-stationary.

The ADF unit root test for the four variables in this research (UN, GR, FEMALE) has shown the probability is less than (5\%). Thus, the null hypothesis of a unit root in return is rejected at least at 5\% significant level. In other words, these variables are stationary in level.

While the ADF unit root test for the remaining variables in the research has shown the probability is more than (5\%). Thus, the null hypothesis of a unit root in return is accepted at least at a $5 \%$ significant level. In other words, these variables are non-stationary in level.

However, for some of these variables, such as EDU, URBAN for the first difference series the null hypothesis of a unit root test is rejected for the four variables at least at a $5 \%$ significant level. It shows that the data series is stationary in the first difference.

We can conclude that variables are integrated of order I (0) and I (1). As all series are joined of a different order, there is a chance that a cointegrating relationship exists among the variables. This is examined in the next section.

After making sure that all variables are integrated in a different order, the next step is to perform the cointegration test. To examine cointegration, we apply the bootstrapping ARDL bounds testing approach to validate the existence of a cointegration relationship amid the variables.

Table 3 reports the results of ARDL Bootstrap cointegration as we can see from Table 3 as FSS is F-statistic for overall model, tDV shows the t-statistic for Dependent variable, tIV presents the $t$-statistics for Independent variable, the cointegrating relationship among the variables at a 5\% significance level.
Table 3 ARDL bootstrap cointegration

\begin{tabular}{lcc}
\hline & \multicolumn{1}{l}{ Value } & \multicolumn{1}{c}{-test } \\
\hline FSS & 1.788779 & 7.187343 \\
tDV & -2.20006 & -4.07031 \\
tIV & 0.520943 & 2.852431 \\
\hline
\end{tabular}

The results of Table 3 confirm that at $5 \%$ significance level the dependent variable, independent variables, and the overall model exhibited long-run relationship.

Table 4 shows the ARDL regression with all the variables except economic growth (GR) and lag of education are statistically significant which emphasizes the existent long-run relationship among the variables.

The impact of economic growth on the Unemployment rate is negative and statistically significant at $10 \%$ significance level. An increase in the growth rate by $1 \%$ will decrease the unemployment rate by about $0.32 \%$. This result is compatible with economic theory (Okun's law) that claimed that there is an inverse linkage between economic growth and unemployment rate.

Lag of unemployment has a positive effect on current unemployment and it is statistically significant at $10 \%$ significance level. It is clear that last year unemployment shows the bad economic situation of country; hence it will have a negative side effect on the current year unemployment. The effect of education on unemployment rate is positive and significant at a $10 \%$ significant level. An increase in the education of $1 \%$ will bring about an increase in the unemployment rate by about $0.21 \%$. Education is one of the most important proxy variables for human capital and has a positive effect on economic growth. Our findings confirm this positive relationship.

The effect of the female population on the unemployment rate is positive and significant. An increase in the proportion of the female population by $1 \%$ will increase the unemployment rate by about $25.01 \%$. It is exactly

Table 4 ARDL regression model

\begin{tabular}{lll}
\hline ARDL regression & & \\
\hline Dependent variable: UN & Coef & $\boldsymbol{t}$-test \\
Variable & 0.46 & 1.83 \\
\hline UN (-1) & 25.01 & 1.93 \\
FEMALE & -0.32 & 1.81 \\
GR & 4.06 & 3.79 \\
URBAN & 0.21 & 1.78 \\
EDU & 834.08 & 4.14 \\
C & & \\
\hline
\end{tabular}


true according to our expectation that the unemployment rate in the female is high in Jordan and still there is gender inequality for the job.

The effect of the urban population on the unemployment rate is positive and significant; an increase in the urban population of $1 \%$ will perform an increase in the unemployment rate by about $4.06 \%$. People in the cities are limited to work in industries, service provider companies, and government jobs, etc., but people in the villages have this chance to farm on different scales while their cost of living is less than the people in the cities.

In the end, we accounted for the diagnostic test to see the reliability of the model and stability of estimations. According to Table 5, the probability value of the Jarque-Bera statistics is $57 \%$ and we cannot reject the null hypothesis. It means that residuals have a normal distribution. There is no serial correlation in the model according to the Breusch-Godfrey LM test and it shows the efficiently estimated coefficients. The result of the Breusch-Pagan-Godfrey test presents homoscedasticity; hence the standard errors and coefficient estimates are more robust and efficient. The probability value ( $P$-Value) of the Ramsey Reset test is more than $10 \%$ which means we cannot reject the null hypothesis. We can conclude that methodology and model are correctly specified.

\section{Conclusion}

Economist studies the unemployment to investigate its causes and how to reduce this phenomenon, unemployment is caused by various reasons, but the main causes are the high growth rate of population and the lack of jobs opportunity and the inefficiency of the public sector these reasons, which can lead to poverty. The main purpose of the study was to establish the relationship between the unemployment and economic growth in Jordan. The studies have been conducted on the unemployment and economic growth and have found various variables influencing on these factors. The present study has developed the case of Jordan and has identified the pattern of economic growth in the country between 1991 and 2019.

In the study, the validity of economic growth about whether it has a contribution to decreasing the

Table 5 Diagnostic tests

\begin{tabular}{|c|c|c|c|}
\hline Test & Null Hypothesis & Value & $P$-Value \\
\hline Jarque-Bera test & $\begin{array}{l}\text { Normally distributed } \\
\text { residuals }\end{array}$ & 1.13 & 0.57 \\
\hline Breusch-Godfrey LM test & No serial correlation & 1.61 & 0.23 \\
\hline $\begin{array}{l}\text { Breusch-Pagan-Godfrey } \\
\text { test }\end{array}$ & Homoscedasticity & 14.35 & 0.11 \\
\hline Ramsey RESET & Stable structure & 3.43 & 0.18 \\
\hline
\end{tabular}

unemployment in the economy has been searched by Okun's Law. For this purpose, we estimated the relationship by using ARDL-regression test results indicate that, indeed, there exists a long-run relationship among the unemployment rate, economic growth, education, urban population, and female population in Jordan.

Moreover, our findings show that economic growth has a negative and significant effect on the unemployment rate in Jordan in the long run. This result confirms the Okun's law that claimed an inverse relationship between the economic growth and unemployment. The negative correlation among the unemployment rate and economic growth indicates that economic growth can be used as an important tool in decreasing and achieving the desired rate of employment rate. Additionally, we found positive relationships among the unemployment rate and female population, urban population, and education. These positive signs were expected with different researches and we found the same results (Al-Manaseer et al. [7], Alshyab et al. [9], Kasoolu et al. [21].

Nowadays, many countries try to develop strategies and plan to expand job opportunities and decrease the existing unemployment rate. The government of Jordan has to focus on creating a proper environment for the private sectors to create more jobs and increase the job opportunities. Also, the government has to attract Arab and foreign investors to invest in Jordan that can improve the economic situation of country. Based on the findings of the research, it is further recommended that government should ease the entrance of firms in the business, removes the limitation of competition in the economic markets, and supports the entrepreneurs especially the female entrepreneurs. The female population has found to have significant impact on the unemployment for the long run and short run, and hence it is implied that the policy makers must focus on this aspect and implement the policies related to the employment of females.

\section{Abbreviations}

ADF: Augmented Dickey-Fuller; ARDL: Auto-regressive distributed lag; DF: Dickey-Fuller; ECM: Enriched culture medium; EDU: Education; GDP: Gross domestic production; GR: Economic growth; ILO: International Labour Organization; OECD: Organization for economic co-operation and development; OLS: Ordinary least square; SAARC: South Asian Association for Regional Cooperation; tDV: T-statistic for dependent variable; tIV: T-statistics for independent variable; VECM: Vector error correction model; UN: Unemployment rate.

\section{Acknowledgements \\ None}

\section{Authors' contributions}

$\mathrm{HH}$ contributed to data curation and writing — original draft preparation. MS contributed to conceptualization, methodology, software, supervision, writing - reviewing and editing. $\mathrm{HO}$ contributed to supervision. All authors have read and approved the manuscript. 


\section{Funding}

There is no funding for this research.

\section{Availability of Data and materials}

All data obtained from the World Bank data set.

\section{Declarations}

\section{Competing interests}

All authors have participated in (a) conception and design, or analysis and interpretation of the data; (b) drafting the article or revising it critically for important intellectual content; and (c) approval of the final version. This manuscript has not been submitted to, nor is under review at, another journal or other publishing venue. The authors have no affiliation with any organization with a direct or indirect financial interest in the subject matter discussed in the manuscript.

Received: 11 February 2021 Accepted: 25 July 2021

Published: 26 December 2021

\section{References}

1. Abdul-Khaliq S, Soufan T, Shihab RA (2014) The relationship between unemployment and economic growth rate in Arab Country. J Econ Sustain Develop 5(9):56-59

2. Ahmed A, Aziz A, Zaman K (2013) The long run effects between unemployment and economic growth in selected SAARC countries. Econ Res Guardian 3(2):70

3. Akeju KF, Olanipekun DB (2014) Unemployment and economic growth in Nigeria. J Econ Sustain Dev 5(4):138-144

4. Alawin M (2013) Trade balance and unemployment in Jordan. Eur Sci J 9(7):143-151

5. Al-Habees MA, Rumman MA (2012) The relationship between unemployment and economic growth in Jordan and some Arab countries. World Appl Sci J 18(5):673-680

6. Ali NNH, Allan M (2017) The role of integrated marketing communications in increasing the efficiency of internet-based marketing among Jordanian consumers. Int J Market Stud 9(4):97-110

7. Al-Manaseer DS, Al-Qudah AM (2018) The impact of higher education output on unemployment rates in Jordan. Int J Acad Res Account Finance Manag Sci 8(2):65-72

8. Al-Sawaiea KM (2020) The relationship between unemployment and economic growth in Jordan: an empirical study using the ARDL approach. Int J Innov Creat Change 14(2):1068-1083

9. Alshyab N, Sandri S, Abu-Lila Z (2018) Skills mismatch and returns to education in Jordan (No. 12). EMNES Working Paper.

10. Amerah M, Khasawneh M (1993) Unemployment in Jordan: dimensions and prospects. Center for international studies, pp. 1-56.

11. Anbaraki L, Ismaili B (2020) Investigating the relationship between drug addiction among youth and unemployment and its impact on urban security in bushehr province. Boushehr Danesh Entezami 10(39):53-64

12. Chand K, Tiwari R, Phuyal M (2017) Economic growth and unemployment rate: an empirical study of Indian economy. PRAGATI: J Indian Econ 4(2):130-137

13. Dahmani MD, Rekrak M (2015) Revisiting the relationship between unemployment rate and economic growth in Algeria, 1970-2014: cointegration approach using ARDL model

14. Efrianti R, Marwa T, Tarmizi N, Yuliana S (2018) Growth, unemployment and its implication on poverty: empirical study in districts/cities of south Sumatera province. Eurasian J Econ Finance 6(4):27-37
15. Eichengreen $B$ (2020) Keynesian economics: can it return if it never died? Rev Keynes Econ 8(1):23-35

16. Folawewo AO, Adeboje OM (2017) Macroeconomic determinants of unemployment: empirical evidence from economic community of West African states. Afr Dev Rev 29(2):197-210

17. Gao G, Liu B, Kouassi I (2017) The contemporaneous effect of unemployment on crime rates: the case of Indiana. Southwestern Economic Review 44:99-107

18. Holmes MJ, Silverstone B (2006) Okun's law, asymmetries and jobless recoveries in the United States: a Markov-switching approach. Econ Lett 92(2):293-299

19. International Labor Organization (2012) Employment working paper no. 118, https://www.ilo.org/wcmsp5/groups/public/---ed_emp/docum ents/publication/wcms_191243.pdf

20. International Monetary Fund (2021) https://www.imf.org/en/Publicatio ns/CR/Issues/2021/01/11/Jordan-First-Review-Under-the-ExtendedFund-Facility-Arrangement-and-Request-for-a-Waiver-of-50003

21. Kasoolu S, Hausmann R, O'Brien T, Santos MA (2019) Female labor in Jordan: a systematic approach to the exclusion puzzle. CID working paper series.

22. Khrais I, ve AI-Wadi M (2016) Economic growth and unemployment relationship: an empirical study for MENA countries. Int J Managerial Stud Res 4(12):19-24

23. Kreishan FM (2011) Economic growth and unemployment: An empirical analysis. J Soc Sci 7(2):228-231

24. Magnani R (2013). The solow growth model with keynesian involuntary unemployment (No. 2013-01).

25. Mihajlović V (2020) The nexus between unemployment and economic growth in Serbia: Does Okun's law hold? Ekonomika preduzeća 68(7-8):484-499

26. Nagel K (2015) Relationships between unemployment and economic growth-the review (results) of the theoretical and empirical research. J Econ Manag 20:64-79

27. Nagelhout GE, Hummel K, de Goeij MC, de Vries H, Kaner E, Lemmens $P$ (2017) How economic recessions and unemployment affect illegal drug use: a systematic realist literature review. Int J Drug Policy 44:69-83

28. Noor ZM, Nor NM, Ghani JA (2007) The relationship between output and unemployment in Malaysia: does Okun's law exist. Int J Econ Manag 1(3):337-344

29. Ojima D (2019) Unemployment and economic development in Nigeria (1980-2017). Adv Soc Sci Res J 6(1):110-121

30. Okun A (1962) Potential GNP: Its Measurement and Significance', in The 1962 Proceedings of Business and Economic Statistics Section. In American Statistical Association

31. Pesaran MH, Shin Y, Smith RJ (2001) Bounds testing approaches to the analysis of level relationships. J Appl Econ 16(3):289-326

32. Rahman MS (2013) Relationship among GDP, per capita GDP, literacy rate and unemployment rate. British J Arts Soc Sci 14(2):169-177

33. Soylu ÖB, Çakmak I, Okur F (2018) Economic growth and unemployment issue: Panel data analysis in Eastern European Countries.

34. Xesibe Z, Nyasha S (2020) Unemployment and economic growth in South Africa: a reexamination. Int J Sustain Econ 12(2):101-116

\section{Publisher's Note}

Springer Nature remains neutral with regard to jurisdictional claims in published maps and institutional affiliations. 